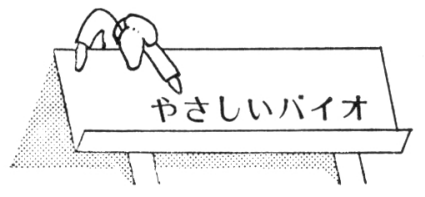

第 23 回

\section{バイオテクノロジーで 何ができるか}

清酒醇造とバイオテクノロジー（1）

過去 2 年間, バイオの主役ともい觉る遺伝子 (DNA), あるいは目的の産物之もい光る酵素等 (タンパク質) の 性質, 及びそ孔らの操作技術等について解説を行ってき ました。これらによってバイオテクノロジーの基礎的な 概念については御理解願えたものと思います。

しかし，これらの概念はどちらかといえば身近なもの ではなく，醸造の実際的な応用にどのように役に立つか イメージがわかなかった方も多かったと思います。

そこで，今回はぐっ之話題を身近にし，これらの技術 によってどのように酒屋が変貌するかを，いささか夢物 語も交觉ながら述べてみたいと思います。バイオテクノ ロジーの基礎的な技術と連想させながらお読み願えれば 幸いです。

\section{1. 麴菌の育種（細胞融合）}

梦菌は米を溶解するための酵素源として重要ですが, その外に清酒に独特の風味を与光る材料としても同様に 重要です。そこでここでは，クエン酸のさわやかな風味 をもった清酒を䴹菌を改変することによって造ることを 考光てみたいと思います。焼酎麥迷は御存じのようにクエ ン酸を多量に作ります。しかし清酒にそのまま使います と香りが悪くなったり，また酸度が過多となるという弊 害が伴います。そこで，清酒麳之焼酎䴹の長所だけを取 り入れた麴菌が望ましいといらことになります。ここで 登場するのが細胞融合です。両方の敕菌の細胞の細胞壁 を除き(プロトプラスト化), PEG 等の細胞融合促進剂 を添加しますと，両者が融合し融合䊝菌ができ上がりま す。これはいわば榃菌の合いの子であるといえなす。こ の中から望ましい性質を持った融合株を選抜すれば，さ わやかな酸味と清酒本来の香味を併せ持った, 新しいタ イプの清酒用憗菌のでき上りです。

\section{2. 澱粉資化酵母の育種（形質転換）}

酵母はもろみの中で専ら発酵を担当し，並行複発酵の
もら一つの重要な働きである糖化は先に述べた㲠菌が行 います。しかし酵母が糖化作用を併せ持てば酵母のみで 並行複発酵を行うことが可能となります。このためには 酵母がアミラーゼを生産することが必要です。このため の手法が形質転換です。酵素（タンパク質）を作るには そのための遺伝子 (DNA) が必要ですが, 酵母はこの遺 伝子を持っていません。そこで，この遺伝子を粎菌の中 から取り出し(クローニング), プラスミド等のベクタ 一に連結し, 酵母に入れてやれば (形質転換) 酵母楼 菌由来のアミラーゼを生産するようになります。

ただこの場合若干の工夫が必要です。焼酎白㮃菌のグ ルコアミラーゼを協会酵母に導入する場合の戦略を考光 てみましょら。粨菌のような真核生物の遺伝子の中には タンパク質に翻訳される部分(エクンン)とそうでない部 分(イントロン) があります。DNA の情報は mRNA に転写されさらにタンパク質に翻訳されるわけですが, 転写の過程で不用なイントロン部分は削除され（スプラ イシング）成熟した mRNA ができ上がります。このス プライシングの機構は酵母と憗菌で若干の差があるため, 棦菌の染色体 DNA（イントロンを有する）を酵母溥 入しても機能しないといら問題点があります。そこでイ ントロンを除去した DNA を用いる必要が出てきま す。そのためには, 次の方法が考光られます。成熟した mRNA はイントロンが除去されていると申しましたが これを利用すれば良いのです。即ら，逆転写酵素を利用 して mRNA と相補的な DNA(cDNA) を合成し用い れば良いのです。たたしこれをとのままべクターにつな いで酵母に導入しても機能しません。というのは，遺伝 子の発現にあたってはプロモータという部分が必須であ り,これは酵母（宿主）由来のものでなければ機能しな いからです。そこで，酵母由来のプロモータ（例兑ば $\mathrm{ADH}$ 1) の下流に cDNA を連結したベクターを構筑 し酵母に導入してやります。これでめでたく発現という ことになります。ただ, プラスミド型のベクターは不安 定で脱落しやすいといら問題点がありますので, 望まし くは染色体 DNA に組又込んでやると安定します。これ で夢の酵母のでき上りです。

\section{3. キラー酵母の育種（細胞質因子導入法）}

清酒醇造に使われるのは協会酵母等の優良䁔造酵母で すが，自然界にはこの他にも野生酵母といわれる酵母が たくさんいます。これらの酵母は清酒も万み中に侵入し, 醸造用酵母之競合し, 時にはそれらを駆逐しもろみを乗 っ取ることもあります。和果, もろ久は発酵が停滞 しまた品質が損なわれます。この対応策としては, 御存 


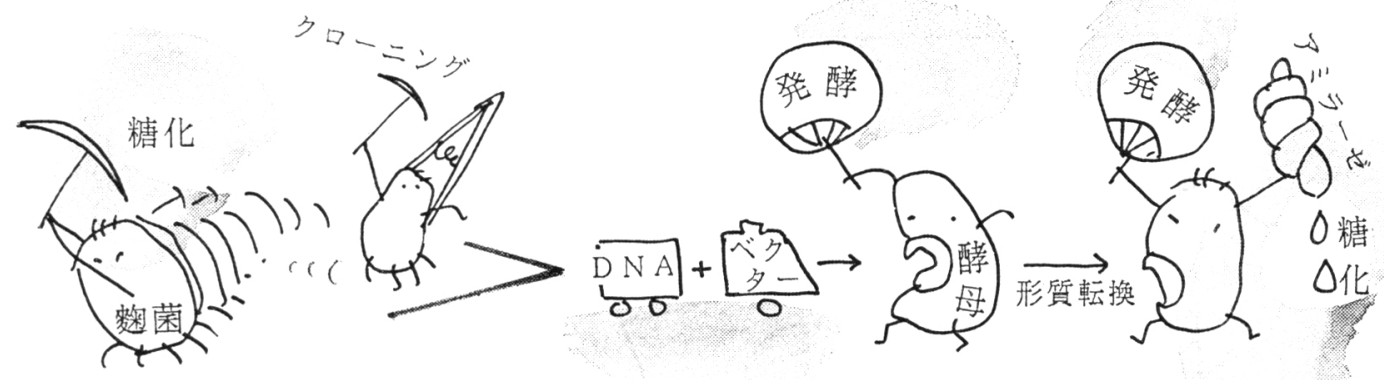

じのように健全な酵母を大量に用

いること、いわば数によってカバーしています。しかし 他にもっと積極的な対応策はないものでしょうか。

次に述べる方法は, 醸造用酵母が自ら身を守る, 即ち 自衛力を身につける方法です。酵母の中には，毒素を外 部汇分泌し他の酵母を殺す働きのあるものがいます。こ れらはその性質からキラー酵母と呼ばれています。協会 酵母の中にはキラー酵母は存在しません。キラー酵母は 細胞質中にプラスミドと呼ばれる核外遗伝子を持ってお り，これがキラー毒素の生産に関与しています。協会䣲 母が自衛力を身につけるにはこのプラスミドを獲得すれ ば良いといらわけです。

このためには, 掛忖合わせ, あるいは細胞融合により 細胞質因子を獲得するといら方法が考光られます。しか しこの方法では協会酵母とキラ一酵母（醸造特性は一般 に良くない）の核が融合し，雑種が形成されてしまい醸 造特性が損なわれてしまいます。協会酵母がほしいのは キラー酵母の細胞質だけで核はいらないのです。そのた めキラ一酵母 (供与菌) は核融合欠損変異株として打き ます。こうして細胞を融合させますと, 協会酵母はキラ 一酵母の細胞質だけを受取り核はそのまま, 即ち優良性 は保存されるわけです。この方法をサイトダクション (細胞質因子導入法)といいます。

\section{4. 酵素の機能強化（タンパク質工学）}

も万又の溶解, 糖化汇必要な酵素は主に数菌が作りま す。通常の発酵の場合は支障がないのですが，時にはも

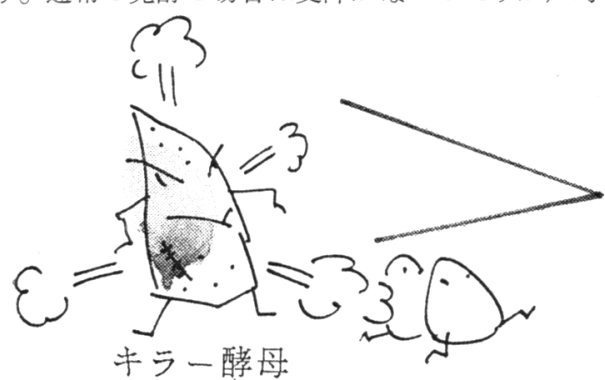

っと強力な醉素がほしいといら時もあります。例完ば高

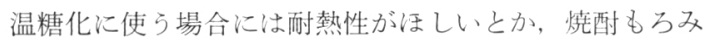
の場合に桜耐酸性, 又りんもろみの場合には耐アルュー ル性とかです。この目的の場合, 他の微生物起源の目的 にあった酵素を捜してくるのも一つの方法ですが、ここ では楼の酵素を人為的に変えるといらことを考兄てみま しょう。この目的使われる手法がタンパク質工学で す。

酵素（タンパク質）の性質は，その立体的な構造（3 次構造）によって決まりますが，本来こ机はアミ，酸配 列 (1 次構造) に上って一義的浪決定されるといら性格 のものです。従ってアミ, 酸配列(これは DNA の塩基

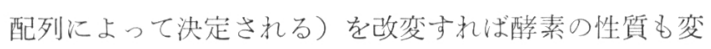
わるといらことになります。酵素の機能と 1 次構造の関 倸は徐々比明かになりつつ峁ります。従ってこれらの 情報を参考にしながらタンパク質をデザインす扎ばよい のです。具体的には、アミラーゼに例をとれば, まず他 の耐熱性酵素の情報を参考にしながら，目的の性質を持 つようにアミノ酸配列をデザインし，これをDNAのコ ード潘訳します。次滀菌のアミラーゼ遺伝子を試験 管中でデザインに従い改変し目的の DNA を得, これを ベクターに連結し麳菌細胞内に導入乙, 䊝菌の遗伝子中 のアミラーゼ遺伝子と入机換党ます。そうすると強力な アミラーゼを作る㸋菌の誕生です。

$$
\begin{aligned}
& \text { 文・伊藤清 } \\
& \text { え・さとう・ひろし }
\end{aligned}
$$

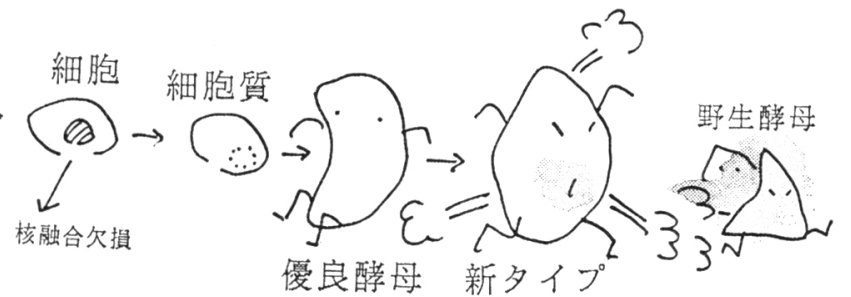

